\title{
Impacts of Zakat Avoidance on the Market Performance of Banks in Saudi Arabia
}

\author{
Dr. Salah Oraby \\ Assistant Professor \\ Accounting Department \\ College of Administrative and Financial Sciences \\ Saudi Electronic University \\ Ammar Abdullah Alhajjaj (MBA) \\ $\mathrm{Ph}$.D. Candidate \\ Al-Imam Mohammad ibn Saud Islamic University
}

\begin{abstract}
This study aims at investigating whether investors in Saudi capital market are aware of the behavior of banks in the field of zakat avoidance especially that zakat dues are treated as a component of equity in balance sheet rather than as an item of income statement and that treatment may give a room to management to manipulate the calculation of the book value per share that is of value relevance. To test research hypotheses two regression models are developed: the first assumes that investors are not aware of zakat avoidance by banks whereas the declared book value per share as the independent variable is regressed on the market value per share as the dependent variable, the second model assumes that investors are aware of zakat avoidance by banks, whereas the adjusted book value per share as the independent variable is regressed on the market value per share as the dependent variable. The two models gave similar results indicating that both book values are of value relevance explaining about $51 \%$ of changes in the market value per share. It can be said that investors are not aware of zakat avoidance by banks and are using the declared book value as the predictor of the market value per share rather than using the adjusted book value. The results of research may be due to the lack of sufficient disclosures by external auditors in some cases and due to the complete absence of disclosures by external auditors in most cases.
\end{abstract}

Keywords: value relevance, book value per share, adjusted book value per share, zakat avoidance.

\section{Research Problem}

The accounting treatment of Zakat expense for financial institutions, including banks, in KSA is different than other entities. The IAS 12.77 states that "the amount of tax expense (or income) related to profit or loss is required to be presented in the statement(s) of profit or loss and other comprehensive income" (IFRS Foundation, 2002, p. A983). The KSA's accounting standards that issued by the Saudi Organization for Certified Public Accountants (SOCPA), also, states that "the Zakat provision shall be presented in separate item in income statement after the exceptional profit/loose items and before the net income item" (SOCPA, 1999, p. 1712). Therefore, all entities shall recognize the Zakat expense in the income statement before the net income item. However, financial institutions (banks, finance company, and insurance) are supervised by the Saudi Arabian Monetary Authority (SAMA), where SAMA requests financial institutions, in its circular number (381000074519) on Apr. 11, 2017, to prepare their financial statements using IFRS standard except IAS 12 that it is related to accounting of Zakat. The circular addresses how to present Zakat in the financial statements as follows: the total amount of Zakat shall be disclosed in the financial statements under the Statement of changes in shareholders' equity and present Zakat for the current year and Zakat for the prior year(s) in separate items.

Indeed, to comprehend the reflection of this difference in treatment of Zakat amount, we will take example for both treatments. If company make one million as an earning before Zakat (EBZ) and two hundred thousand as a Zakat amount, the net income using the treatment that banks use in KSA is one million. Whereas, the net income for company that following International Financial Reporting Standards (IFRS) or SOCPA will be only eight hundred thousand netting of tax expense. Consequently, this difference in accounting treatment may misleading investment decisions for investors who do not aware about it.

As a result of SAMA abovementioned circular, the banks' net profit will not be affected by either Zakat provisions or Zakatpaid. Therefore, Zakat avoidance in KSA banks under current accounting treatment, will affect the equity in the bank's balance sheet. Moreover, there is variation in calculating Zakat base between the General Authority of Zakat and Tax (GAZT) and the banks that subject to Zakat in KSA. 
Hence, Zakat avoidance could affect the banks book value per share, when they are paying less amount of Zakat, which might positively affect the market price of the bank's shares. previous studies such asOraby (2017) pointed out that the book value per share is of value relevance, which means that the investors depend on it in their investment decision in banks listed in the Saudi Stock Exchange (Tadawul). Therefore, this research will shade the light on the impact of Zakat avoidance of the listed KSA's banks on the investors' decisions in Tadawul. The research question will be: whether or not the investors in Tadawul are aware of the impact of Zakat avoidance of the listed KSA's banks when they make their investment decisions?

\section{Research Importance}

This research is very important for many parties such as investors in Tadawul, external auditors, government, and researchers in the accounting field. Indeed, the external auditor role is very important to investors and the regulators. Where the external auditors are responsible for disclosing any concern that might be financially affect the company either in the current year or in the future. However, in the researcher perspective, the external auditors did not disclose the Zakat issue in KSA's banks as it should. In 2017, out of twelve banks there are two banks (Ahli, ANB) their external auditor (EY, KPMG) did not mention any thing about Zakat issue in their reports, whilst there are only three auditors conduct external auditing for all KSA's banks (EY, KPMG, PWC). However, the other external auditors for the rest banks presented the differences in Zakat between banks and GAZT in mysteriously ways. For example, EY and PWC as external auditors for Riyad bank wrote in their report in 2017 annual report of Riyad bank the following text: The Group submit the Zakat declaration annually to GAZT. GAZT conduct assessment for years 2008-2013 which result substantial additional Zakat claims from GAZT by SAR 3.5 billion. The reason of this additional claim is because GAZT did not deduct the long-term investments and added the long-term debts for the Zakat base. The group did not accept GAZT interpretation, and object to the relevant committees.

Assessment did not conduct for years 2014 and beyond, and based on previous assessments, if the long-term investment deducted and long-term debt added to the Zakat base, this will establish substantial additional Zakat claims. The potential amounts of any additional Zakat claims are not disclosed in the consolidated financial statements, as management believes that such disclosure could result in damage to the Bank on this issue. Management has made estimates on this issue and the extent of the Zakat obligations (depending on the future result of GAZT assessment), based on these estimates, the management expects the outcome of the objections to be in its favor. We have considered this issue to be a key audit point because it requires significant estimates by the management and that additional claims from GAZTcould be substantial to the consolidated financial statements.(Riyad Bank, 2018, p. 6)

However, most external auditors wrote almost similar text in their report in 2017, which is, in the research opinion, not enough for investor to understand what is going in this issue, and even they mention that this issue could have substantial effect to the future financial statements, while they did not report if the banks formed adequate allowances against this issue or explain how the management estimates this issue.

Apparently, according to the practice, the external auditors be the agent of the bank in submission of the objection and provide consultation on this issue to them, which may create a conflict of interest that led to not disclose this issue clearly in the external auditor reports. The delay that occur from GAZT in assessing the banks' declarations and lack of announcement, on the other hand, further complicates this issue and increasing uncertainty with the investors in Tadawul. This issue impacts, also, the stock market from side that the level of transparency in the market will be decrease, which reduce the market attractiveness of investors. Furthermore, the foreign direct investors will be reluctant to invest in Tadawul, thus minimize the flow of hard currency to KSA. Inequality of investment opportunities, where few investors aware about this issue because they access to information that other investors cannot access.

Another aspect to importance of this research is the effect of the Zakat avoidance on the government revenue. Seemingly, the government losses huge amount of revenue that assumed to be collected from banks as a Zakat as the appendix 1 shows, whereas The government lost about five billion yearly as the appendix 1 shows, and banks only paid $28.42 \%$ of the Zakat that should have been paid by banks in accordance with the laws as an average of the last four years.

\section{Research Objectives:}

The research aims to investigate whether the investors in Tadawul are aware about the impact of KSA's banks Zakat avoidance when they evaluate the bank's market price. Thus, the market price per share for these banks will be affected by the results of Zakat avoidance. As this issue has been addressed by the media recently and investors become worried about it, this research tries to clarify this issue by this empirical research using the historical data to evaluate the investors' behavior in this issue. 
The statistical tools will be used to achieve the objective of this research, in addition results of this research could be used as indicator for predicting the future behavior of the banks' investors.

\section{Research Methodology:}

This section will illustrate the methodology that has been adopted in the research, sample design, data design, and the research approach. However, this research is a quantitative study that aims to discover if there is a significant difference between the Zakat paid by the listed KSA's banks and the Zakat that they should have been paid according to the Zakat executive regulations, and if there is a significant difference when using the book value per share and the adjusted book value per share as determinants for predicting share prices. Moreover, the direction and the significance of the relationship between the book value per share and the market value per share. To achieve that, the research is using the regression and correlation models to measure the influence and relationships between the study variables, and t-test to measure the level of difference between the variables. Secondary data will be used in this research, which is collected from the financial statements of the sample and the shares market price within the scope of the study to all KSA's banks (the sample), which is published in Tadawul website (www.tadawul.com.sa).

The research is using purposive sampling, where the researcher selected specific years of all KSA's banks that listed in Tadawul which subject to Zakat as a sample of this study. However, the branches of foreign banks and the part of the banks that is not subject to Zakat, which is own by foreign investors are excluded from the sample, because they are not subject to Zakat according to the Zakat executive regulations (NCAR, 2017). This research is using the inductive approach by using the different resources that related to the research subject in order to build the research hypotheses and the deductive approach is used to examine the research hypotheses and analyze the research's results in order to generalize it.

\section{Research Hypotheses:}

To achieve research objectives and recognize whether or not investors in Tadawul are aware of the impact of Zakat avoidance of the listed KSA's banks when they make their investments decisions, four hypotheses could be developed as follows:

1. There are no statistically significant differences between Zakat paid by banks and the Zakat that should have been paid by banks according to the Zakat executive regulations.

2. There are no statistically significant differences between the declared book value per share under Zakat avoidance and the adjusted book value per share.

3. There is no a statistically significant relationship between the declared book value per share under Zakat avoidance as an independent variable and the market value per share as a dependent variable.

4. There is no a statistically significant relationship between the adjusted book value per share in the absence of Zakat avoidance as an independent variable and the market value per share as a dependent variable.

\section{Literature Review:}

After reviewing the previous studies and articles about market performance under Zakat avoidance in KSA, the research found that there are no articles in this area. Moreover, the research found there are very few articles about Zakat avoidance in KSA or other countries. "Although there are some studies in the area of tax evasion, with regard to Zakat evasion studies are almost rare or nonexistent" (Alsaad, 2013, p. 13). However, Johari, Aziz, \& Ali (2014) review articles about Zakat, in general, for period from 2003 to 2013 and they found 108 articles, only five articles of them are belong to Zakat in KSA. Apparently, this scarcity of articles in this area is due to many reasons, few countries apply compulsory Zakat, thus avoidance occurred only under compulsory Zakat application. Ambiguity in how to calculate Zakat base in KSA is another influential factor led to lack of articles in this area. In light of this scarcity of articles, the researcher focuses on articles that discussed any issue of Zakat in KSA or the market performance that related to the value relevant of book value per share in the banking sector in KSA.

The nearest study to the research topic is Alsaad (2013), where the study aims to explore the methods, reasons, and forms of Zakat evasion in KSA both theoretically and practically. The study using a theoretical conductive approach of research, where the study pursued evidences, opinions, rules, texts, and Shariah law to answer the study's questions. The study using a questionnaire that designed to collect primary data from random sample of GAZT employees and certified public accountant in KSA. The study found that there are some Zakat evasion behaviors conducted by Zakat payers, such as filing fake financial information and not disclosing one or more activities that are subject to Zakat. However, the study found that Zakat evasion occur because of many reasons, like fear of not delivering Zakat to right beneficiaries, absence of sanctions on Zakat evasion, and vagueness in Zakat regulations. 
The recommendations that study's reaches are many, however, the most important recommendations are Zakat distribution by the government should be disclosed in way that removes Zakat payers fear, Zakat regulations should be clearer and GAZT must conduct awareness campaigns to reduce the ambiguity, and imposing sanctions on the Zakat evasion. Aljabr \&Alsehali (2006) seeking for exploring the working methodology of the First Instance Zakat and Tax Committees (FIZTC) in KSA and the obsticals that FIZTC may face during doing its job. The study conduct in depth interviews to collect the data, and conclude that FIZTC depends heavily on one of their members to judge the objections, the settlement of Zakat objections are more difficult than tax objections, FIZTC pay special attention to the letter of objection, and the study disclosed many obstacles that hinder FIZTC work and suggest solutions to increase the effectiveness of FIZTC.Bashi \& Mansor (2005) study entitled "Using the Balance Sheet Statement to Calculate Zakat on Trade" which seems to using a qualititive method of research and inductive approach to answer the study's question. The study dealt with three aspects; balance sheet concept according to accounting theory, the properties' that are subject to Zakat, and preparing balance sheet suitable to calculate Zakat base using net Zakatable assets and net fund resources methods.

There are many articles that the market performance and value relevant of book value per share in banking sector in KSA. Oraby (2017) focus on KSA's listed banks to determine if accounting information under IFRS is of value relevance or not and which accounting information is the more value relevance. Oraby (2017) conducted a quantitative research to examine eleven listed KSA banks in Tadawul for period from 2006 to 2015. The study found that both earning per share and book value per share are of value relevance butearning per share is more value relevance than the book value per share. Al Barrak (2011) conducted a study using Ohlson (1995) and Easton and Harris (1991) frameworks to examine the relationship between market value and accounting information. The KSA's listed in Tadawul companies has been used as a sample of the study for period from 1993 to 2009, excluding banking and insurance sectors. The study found that the book value per share coefficients in all years are significant, the explanatory power of the price model declined in the period after 2003 but it was increasing for period from 1993 to 2003, the explanatory power of the return model presented no significant changes during the study's time frame, and for lossmaking companies the study found that earnings are not value relevant in equity valuation but book value per share is value relevant for periods from 1994 to 2004 and 1993 to 1997.

\section{Empirical Research:}

This section addresses sample selection, data collection, statistical results and testing hypotheses

\subsection{Sample selection:}

The sample of this study includes all KSA's listed banks as presented in the appendix 2 . However, the study covered four financial years from 2014 to 2017, which is published in Tadawul website. Choosing this sample because these are only banks operating in KSA that subject to Zakat, where other banks are branches of foreign banks which is subject to income tax law.

\subsection{Data collection:}

In this study, there are two types of data have been used to test the research hypotheses. The first type of data is regarding to the total Zakat revenue that government collected during the research period,the second type of data is regarding to total Zakat paid by banks under Zakat avoidance and total Zakat assumed to be paid according to the Zakat executive regulations (see appendix 1).

Appendix1shows that banks paid only 27.29\%, 28.52\%, 27.27, and 30.35\% for years 2014, 2015, 2016, and 2017, which is $28.42 \%$ by average of the Zakat that KSA's Banks should paid according to the law. However, the actual Zakat paid by banks composed $14.31 \%$ of the total Zakat revenue by average for years from 2014 to 2017 under Zakat avoidance. While the Zakat should contribute about $37.01 \%$ of the total Zakat revenue by average for years from 2014 to 2017 with absence of Zakat avoidance.

Appendix 3presents three figures for each bank for four years, from 2014 to 2017, the figures are the book value per share, adjusted book value per share, and market value per share. While the book value per share calculated by dividing shareholders' equity on the number of common shares. However, as the zakat avoidance affecting the shareholders' equity in KSA's banks, according to SAMA instructions, the shareholders' equity will be adjusted by add the difference between actual paid Zakat and Zakat assumed to be paid according to the Zakat executive regulations, then divide the adjusted shareholders' equity on the number of common shares. Likewise, the market value per share is the share closing price at the day where the annual financial result of the bank is announced in Tadawul for each year to each bank. 


\subsection{Descriptive Statistics}

Table 1: Descriptive Statistics

\begin{tabular}{|c|c|c|c|c|c|c|c|c|c|}
\hline & & N & Donar & Minimum & Mrimum & Mean & & Ctd Doriotion & Voriomo \\
\hline & & $\mathbf{N}$ & |Range & |vinimum & Miaximum & Statistic & Std. Error & ation & | varrance \\
\hline Paid Zakat & & 48 & $1,305,461$ & 10,881 & $1,316,342$ & $171,020.41$ & $44,542.32$ & $308,598.29$ & $9.523 \mathrm{E} 10$ \\
\hline $\begin{array}{l}\text { Assumed } \\
\text { Zakat }\end{array}$ & Paid & 48 & $1,644,417$ & 129,709 & $1,774,126$ & $601,812.10$ & $61,230.04$ & $424,214.19$ & $1.800 \mathrm{E} 11$ \\
\hline
\end{tabular}

Outputs of SPSS software, numbers in thousand.

Table 1 shows that the sample size is forty-eight for all variables. However, the minimum paid Zakat is SAR10, 881,000 while in assumed paid Zakat is SAR129, 709,000. The maximum in paid Zakat is SAR1, 316,342,000 and in assumed paid Zakat is 1,774,126,000. The paid Zakat mean is SAR171, 020,320 and the mean of assumed paid Zakat equal SAR601, 812,100. On the other hand, the standard deviation of paid Zakat is SAR308, 598,290 while for assumed paid Zakat equal SAR424, 214,190.

Table 2: Descriptive Statistics

\begin{tabular}{|l|l|l|l|l|l|l|l|l|}
\hline & N & Range & Minimum & Maximum & \multicolumn{2}{l|}{ Mean } & Std. Deviation & Variance \\
\cline { 5 - 9 } Book Value & 48 & 23.23 & 11.08 & 34.31 & 20.21 & 0.92 & 6.40 & 40.924 \\
\hline $\begin{array}{l}\text { Adjusted Book } \\
\text { Value }\end{array}$ & 48 & 22.89 & 10.89 & 33.78 & 19.87 & 0.92 & 6.36 & 40.385 \\
\hline Market Value & 48 & 62.13 & 8.92 & 71.05 & 23.95 & 1.91 & 13.20 & 174.25 \\
\hline
\end{tabular}

Outputs of SPSS software.

Table 2 shows the descriptive statistics for the following factors, book value per share, adjusted book value per share, and market value per share. Where the minimum, maximum, mean, standard deviation, and variance for the book value per share are $11.08,34.31,20.21,6.40$, and 40.924 respectively. Whereas, the minimum, maximum, mean, standard deviation, and variance for the adjusted book value per share are 10.89, 33.78, 19.87, 6.36, and 4.385 respectively. Likewise, the market value per share shows minimum 8.92, maximum 71.05, mean 23.95, standard deviation 13.20, and variance 174.25 .

\subsection{Testing Hypotheses:}

In this section statistical models are used to test research hypotheses as follows:

Hypothesis 1; There are no statistically significant differences between Zakat paid by banks and the Zakat that should have been paid by banks according to the Zakat executive regulations.

Table 3: Test for differences in Zakat dues

\begin{tabular}{|c|c|c|c|c|c|c|c|c|c|}
\hline & $F$ & Sig. & $\mathrm{t}$ & $\mathrm{df}$ & $\begin{array}{l}\text { Sig. (2- } \\
\text { tailed) }\end{array}$ & $\begin{array}{l}\text { Mean } \\
\text { Difference }\end{array}$ & $\begin{array}{l}\text { Std. Error } \\
\text { Difference }\end{array}$ & Lower & Upper \\
\hline $\begin{array}{l}\text { Equal } \\
\text { Variances } \\
\text { Assumed }\end{array}$ & 10.113 & .002 & $(5.689)$ & 94 & .000 & $\begin{array}{l}430,791 \\
6875000 \\
000\end{array}$ & $\begin{array}{l}75,717.4 \\
827754 \\
713\end{array}$ & $\begin{array}{l}581,130 . \\
5245097 \\
962\end{array}$ & $\begin{array}{l}280,452 \\
8500384902 \\
038\end{array}$ \\
\hline $\begin{array}{l}\text { Equal } \\
\text { Variances Not } \\
\text { Assumed }\end{array}$ & & & $(5.689)$ & 85.861 & .000 & $\begin{array}{l}430,791 \\
6875000 \\
000\end{array}$ & $\begin{array}{l}430,791 \\
687500 \\
000\end{array}$ & $\begin{array}{l}581,316 \\
5287635 \\
709\end{array}$ & $\begin{array}{l}280,266 \\
8462364 \\
290\end{array}$ \\
\hline
\end{tabular}

Outputs of SPSS software. 
The above table 3 shows the result of using t-test to compare the differences between the Zakat paid by banks and the Zakat that should have been paid by banks according to the Zakat executive regulations. In fact, the table shows that $\mathrm{F}$ test 10.113 , significance 0.002 , t-test -5.689 , degrees of freedom 85.861, two-tailed significance 0.000 , and mean difference 75,717.483.

In order to know if there are differences between the Zakat paid by banks and the Zakat that should be paid by banks according to the Zakat executive regulations the research has been used t-test. The test shows that variance is not equal because significance less than 0.05 which means that there are differences between the two observations. However, shows that $t$ equal -5.689 which is superior to the standard value of 1.96, then it shows that there is big difference between paid Zakat and assumed paid Zakat. This is supported by the significance of the test, since the significance of the test equal 0.002 which is less than 0.05 . Consequently, we can decide that there are statistically significant differences between the Zakat paid by banks and the Zakat that should be paid by banks according to the Zakat executive regulations, so $\mathrm{H} 1$ is rejected. In essence, this deference is explained by Fisher-test which equal 10.113which is much larger than the standard value of 1.96 .

\section{Hypothesis 2:}

Hypothesis two (H2) is "There are no statistically significant differences between the declared book value per share under Zakat avoidance and the adjusted book value per share". Table 4 shows the results from SPSS software for analyzing this hypothesis 2 using t-test.

Table 4: $\mathrm{t}$ test for differences in book values per share

\begin{tabular}{|l|l|l|l|l|l|l|l|l|l|}
\hline & $\mathrm{F}$ & Sig. & $\mathrm{t}$ & $\mathrm{df}$ & $\begin{array}{l}\text { Sig. } \\
(2- \\
\text { tailed) }\end{array}$ & $\begin{array}{l}\text { Mean } \\
\text { Difference }\end{array}$ & $\begin{array}{l}\text { Std. Error } \\
\text { Difference }\end{array}$ & & \\
Lower & & \\
\hline $\begin{array}{l}\text { Equal } \\
\text { Variances } \\
\text { Assumed }\end{array}$ & 000 & 0.987 & 0.256 & 94 & 0.799 & $\begin{array}{l}0.332918 \\
60333\end{array}$ & $\begin{array}{l}1.301512 \\
77468\end{array}$ & $\begin{array}{l}(251265) \\
52067\end{array}$ & $\begin{array}{l}2.917102 \\
72734\end{array}$ \\
\hline $\begin{array}{l}\text { Equal } \\
\text { Variances } \\
\text { Not } \\
\text { Assumed }\end{array}$ & & & 0.256 & 93.996 & 0.799 & $\begin{array}{l}0.332918 \\
60333\end{array}$ & $\begin{array}{l}1.301512 \\
77468\end{array}$ & $\begin{array}{l}(2.251267) \\
00532\end{array}$ & 2.917104 \\
21199 \\
\hline
\end{tabular}

Outputs of SPSS software.

The above table shows the result of using t-test to compare the differences between the book value per share in the shade of Zakat avoidance and the adjusted book value per share in the absence of Zakat avoidance. Indeed, the table shows that fisher test 0.000 , significance 0.987

In order to know if there are differences between the book value per share in the shade of Zakat avoidance and the adjusted book value per share in the absence of Zakat avoidance the research has been used t-test. The test shows that variance is almost equal because significance more than 0.05 which means that there are no differences between the two observations. However, the test shows that t equal 0.256 which is superior to the standard value of 1.96 , then it shows that there is no different between book value per share and adjusted book value per share. This is supported by the significance of the test, since the significance of the test equal 0.987 which is more than 0.05 .

Consequently, we can decide that there are no statistically significant differences between the book value per share in the shade of Zakat avoidance and the adjusted book value per share in the absence of Zakat avoidance, so H2 is accepted. In essence, this result is explained by Fisher-test which equal 0.000 which is much less than the standard value of 1.96 .

\section{Hypothesis 3:}

Hypothesis 3: There isno a statistically significant relationship between the declared book value per share under Zakat avoidance as an independent variable and the market value per share as a dependent variable. The following model is developed:

$Y=\beta 0+\beta 1 \times 1+\varepsilon(1)$

Where $\mathrm{Y}$ the market price of the bank closing price at the day where the annual financial result of the bank is announced in Tadawul, where the stock price reflected by the financial results. X1 is the book value per share under Zakat avoidance, $\beta 0$ is the constant, $\beta 1$ is the coefficient, and $\varepsilon$ is the error. 
Table 5: Correlation Results for Model 1

\begin{tabular}{|l|l|l|}
\hline Pearson Correlation & MV & BV \\
\hline MV & 1.000 & 721 \\
\hline BV & .721 & 1.000 \\
\hline Sig. (1-tailed) & & \\
\hline MV & .000 & \\
\hline BV & & .000 \\
\hline
\end{tabular}

Outputs of SPSS software.

Table 6: Results of Model 1

\begin{tabular}{|l|l|l|l|l|l|l|l|l|l|}
\hline $\mathrm{R}$ & R Square & $\begin{array}{l}\text { Adjusted R } \\
\text { Square }\end{array}$ & $\begin{array}{l}\text { Std. Error } \\
\text { of the } \\
\text { Estimate }\end{array}$ & $\begin{array}{l}\text { Durbin- } \\
\text { Watson }\end{array}$ & F & Sig. & Beta & t & Sig \\
\hline 0.721 & 0.520 & 0.510 & 9.244560 & 1.077 & 49.826 & 0.000 & 0.721 & 7.059 & 0.000 \\
\hline
\end{tabular}

Predictors: (Constant), BV, Dependent Variable: MV, Outputs of SPSS software.

Previous tables 5,6 provide correlation and regression results, whereas Pearson correlation is significance between book value per share and market value per share is 0.721 . On the other hand, the regression results as follow: $\mathrm{R} 0.721, \mathrm{R}$ square 0.520, adjusted $\mathrm{R}$ square 0.510, standard error of the estimate 9.245, and Dufbin-Watson 1.077. ANOVA test shows that Fisher test is 49.826 and significance equal 0.000 .

$\mathrm{H} 3$ statistical test results show that there is a relationship between the book value per share under Zakat avoidance as an independent variable and the market value per share as a dependent variable. Whereas, Pearson correlation equal 0.721 which is an acceptable level of relationship between the two variables. Indeed, this correlation is significant at the 0.01 level, which is less than 0.05 and confirmed the positive correlation between the book value per share under Zakat avoidance and the market value per share. On the other hand, the regression test shows that $\mathrm{R} 0.721$ and $\mathrm{R}$ square 0.510 , which means that the book value per share composed $51 \%$ of investors' consideration on evaluating the market value per share.

Based on these results, H3 is rejected because there is statistically significant relationship between the declared book value per share under Zakat avoidance as an independent variable and the market value per share as a dependent variable.

\section{Hypothesis 4:}

Hypothesis 4: There is no a statistically significant relationship between the adjusted book value per share as an independent variable and the market value per share as a dependent variable. The following model is developed:

$\mathrm{Y}=\beta 0+\beta 1 \times 2+\varepsilon(2)$

Where Y the market price of the bank closing price at the day where the annual financial result of the bank is announced in Tadawul, where the stock price reflected by the financial results. X2 is the adjusted book value per share, $\beta 0$ is the constant, $\beta 1$ is the coefficient, and $\varepsilon$ is the error

Table 7: Correlation Results Model 2

\begin{tabular}{|l|l|l|}
\hline Pearson Correlation & MV & BV \\
\hline MV & 1.000 & 0.72 \\
\hline ABV & 0.72 & 1.000 \\
\hline Sig. (1-tailed) & & \\
\hline MV & .000 & \\
\hline ABV & & .000 \\
\hline N & BV & BV \\
\hline
\end{tabular}

Correlation is significant at the 0.01 level (2-tailed). Outputs of SPSS software.

Table 8: Results of Model 2

\begin{tabular}{|l|l|l|l|l|l|l|l|l|l|}
\hline $\mathrm{R}$ & R Square & $\begin{array}{l}\text { Adjusted R } \\
\text { Square }\end{array}$ & $\begin{array}{l}\text { Std. Error } \\
\text { of the } \\
\text { Estimate }\end{array}$ & $\begin{array}{l}\text { Durbin- } \\
\text { Watson }\end{array}$ & F & Sig. & Beta & t & Sig \\
\hline 0.720 & 0.519 & 0.508 & 9.258165 & 1.069 & 49.545 & .000 & 0.720 & 7.039 & .000 \\
\hline
\end{tabular}

Predictors: (Constant), A BV, Dependent Variable: MV Outputs of SPSS software. 
H4 statistical test results show that there is relationship between the adjusted book value per share in the absence of Zakat avoidance as an independent variable and the market value per share as a dependent variable. Whereas, Pearson correlation equal 0.720 which is an acceptable level of relationship between the two variables. Indeed, this correlation is significant at the 0.01 level, which is less than 0.05 and confirmed the positive correlation between the adjusted book value per share in the absence of Zakat avoidance and the market value per share. On the other hand, the regression test shows in table 8 that R 0.720 and R square 0.519 , which means that the adjusted book value per share composed 51.9\% of investors' consideration on evaluating the market value per share.

$\mathrm{H} 4$ is rejected because there is statistically significant relationship between the adjusted book value per share in the absence of Zakat avoidance as an independent variable and the market value per share as a dependent variable.

\section{Conclusions:}

This study aims at investigating whether investors in Saudi capital market are aware of the behavior of banks in the field of zakat avoidance especially that zakat dues are treated as a component of equity in balance sheet rather than as an item of income statement and that treatment may give a room to management to manipulate the calculation of the book value per share that is of value relevance. The methodology used to achieve the research objective is to assume firstly that investors are not aware of zakat avoidance and then they use the declared book value per share when making decisions in valuing stocks and secondly investors are aware of zakat avoidance and then they will adjust down the calculation of book value per share when making decisions in valuing stocks. To test research hypotheses two regression models are developed the first assumes that investors are not aware of zakat avoidance by banks whereas declared book value per share as independent variable is regressed on market value per share as dependent variable, the second model assumes that investors are aware of zakat avoidance by banks, whereas adjusted book value per share as independent variable is regressed on market value per share as dependent variable.

The two models gave similar results indicating that both book values are of value relevance explaining about $51 \%$ of changes in market value per share. It can be said that investors are not aware of zakat avoidance by banks and are using the declared book value as predictor of market value per share rather than usingthe adjusted book value.The results of research may be due to the lack of sufficient disclosures by external auditors in some cases and the complete absence of disclosures by external auditors in most cases.

$\mathrm{T}$ test results supported the regression results whereas no significant statistical differences between the book value declared and adjusted book value.Recently a compromise has been reached between banks and zakat authority regarding zakat dues supporting point of view of zakat authority.

\section{Recommendations:}

The researcher finds some points that could be recommended for the concerned parties:

1- Improve the way that external auditors note about banks Zakat behaviors, and expected impacts on the bank.

2-Impose penalty on Zakat late payment or not pay an accurate Zakat.

Accelerates solve the Zakat calculation problem of banks by the legislators, and in case of not find solution the banks could be subject to corporate income tax rather than Zakat.

3. The research recommend that it is important to separate the role of providing Zakat advising and external auditing, and the role of litigation and objection in different firms.

\section{References}

AAOIFI. (2015). Sari'ah Standards. Manama: Accounting and Auditing Organization for Islamic Financial Institutions (AAOIFI).

Abdulhamed, M. (2009). Zakat Institutions and Assessment of Their Economic Role. Amman: Dar Alhamed.

Ali, A. J. (2015). Handbook of Research on Islamic Business Ethics. Edward Elgar Publishing.

Alsaad, S. A. (2013). Zakat Evasion in Saudi Arabia: Its Methods, Forms and the Ways of Dealing with it: An Empirical Study. King Abdulaziz University Journal: Economics and Management, 2(27), 3-106.

Argaam. (2018, Feb. 15). Alinma Bank asked to pay SAR 1.7 bln extra zakat liability. Retrieved from Argaam.com: https://www.argaam.com/en/article/articledetail/id/530381

Güncelleme, S. (2018, Apr. 5). Fitch: Remaining Zakat Bill Assessments Key to Saudi Bank Impact. Retrieved from CNN: https://www.cnnturk.com/yurttan-haberler/istanbul/fitch-remaining-zakat-bill-assessments-key-to-saudibank-impact 1525419607

Hamilton, A. (2018, Feb. 23). Saudi banks challenge new zakat tax requirements. Retrieved from IBS Intelligence: https://ibsintelligence.com/ibs-journal/ibs-news/saudi-banks-challenge-new-zakat-tax-requirements/ 
IFRS Foundation. (2002). IFRS Standards: IAS 12. London: IFRS Foundation.

Income Tax Law. (2004, Mar. 6). Retrieved from World Trade Organization (WTO): https://www.wto.org/english/thewto_e/acc_e/sau_e/WTACCSAU59A2_LEG_8.pdf

Jaelani, A. (2016). Zakat Accounting: Metaphor and Accounting Treatment for Business Organization. The 4th International Conference On Islamic Economice and Business (ICONIES 4th) (pp. 154-171). Malang: Maulana Malik Ibrahim State Islamic University.

NCAR. (2017, Apr. 13). Executive Regulations of the Royal Decree no. (M/40) of 2/7/1405 AH. Retrieved from National Center for Archives and Records (NCAR): http://www.ncar.gov.sa/Documents/Details?Id=d5ELi8y\%2F1\%2FLXyLZuP6yNWA\%3D\%3D

Oraby, S. A. (2017). IFRS and Accounting Information Relevance: The Case of Saudi Arabia. Journal of Business \& Economic Policy, 145-155.

Rashad, M., \& Arnold, T. (2018, Mar. 7). Saudi crown prince seeks solution to banks' \$2.6 billion Islamic tax row: sources. Retrieved from Reuters: https://www.reuters.com/article/us-britain-saudi-banks/saudi-crown-princeseeks-solution-to-banks-2-6-billion-islamic-tax-row-sources-idUSKCN1GJ17V

Rashad, M., Arnold, T., \& Azhar, S. (2018, Feb. 22). Jump in Islamic tax liabilities worries Saudi banks. Retrieved from Reuters: https://www.reuters.com/article/us-saudi-banks/jump-in-islamic-tax-liabilities-worries-saudibanks-idUSKCN1G61LU

Riyad Bank. (2018, Feb. 14). Riyad Bank - Statments. Retrieved from Tadawul: https://www.tadawul.com.sa/wps/portal/tadawul/market-participants/issuers/issuers-directory/companydetails/!ut/p/z1/04_Sj9CPykssy0xPLMnMz0vMAfljo8zi_Tx8nD0MLIy83V1DjA0czVx8nYP8PI0MDAz0I4E KzBEKDEJDLYEKjJ0DA11MjQzcTfW99KPSc_KTIGZllJQUWKkaqBqUJKYklpfmqBroRy

SABIC. (n.d.). About. Retrieved Oct. 23, 2018, from SABIC: https://www.sabic.com/en/about

SOCPA. (1999, Dec. 1). Zakat Accounting Standard. Retrieved from audi Organization for Certified Public Accountants (SOCPA): https://socpa.org.sa/SOCPA/files/89/89a10c94-61d8-4a07-aade-a6f5cf53db65.pdf

Tadawul. (n.d.). 2010 SABIC. Retrieved Oct 23, 2018, from Tadawul: https://www.tadawul.com.sa/wps/portal/tadawul/market-participants/issuers/issuers-directory/companydetails/!ut/p/z1/04_Sj9CPykssy0xPLMnMz0vMAfIjo8zi_Tx8nD0MLIy83V1DjA0czVx8nYP8PI0MDAz0I4E KzBEKDEJDLYEKjJ0DA11MjQzcTfW99KPSc_KTIGZllJQUWKkaqBqUJKYklpfmqBroRy

Tadawul. (2018, Mar. 14). 2010 Statements Retrieved from Tadawul: https://www.tadawul.com.sa/wps/portal/tadawul/market-participants/issuers/issuers-directory/companydetails/!ut/p/z1/04_Sj9CPykssy0xPLMnMz0vMAfIjo8zi_Tx8nD0MLIy83V1DjA0czVx8nYP8PI0MDAz0I4E KzBEKDEJDLYEKjJ0DA11MjQzcTfW99KPSc_KTIGZllJQUWKkaqBqUJKYklpfmqBroRy

Trabelsi, N. S., \& Trabelsi, M. (2014). The Value Relevance of IFRS in the UAE Banking Industry: Empirical Evidence from Dubai Financial Market, 2008-2013. International Journal of Academic Research in Accounting, Finance and Management Sciences, 4(4), 60-71.

Zakat Law. (2001). Retrieved from Zakat-Chamber.gov.sd: http://www.zakat-chamber.gov.sd/arabic/index.php/201207-05-09-11-58/2012-07-22-14-46-56

Appendix 1: ZAKAT DUES

\begin{tabular}{|c|c|c|c|c|c|}
\hline, 000 & $\begin{array}{c}\text { Total Zakat } \\
\text { RAR }\end{array}$ & $\begin{array}{c}\text { Actual Banks } \\
\text { Contribution }\end{array}$ & $\begin{array}{c}\text { Assumed Banks } \\
\text { Contribution }\end{array}$ & $\begin{array}{c}\text { Actual/Assumed } \\
\text { Banks Contribution }\end{array}$ & Different \\
\hline 2014 & $14,170,000$ & $1,742,541$ & $6,386,064$ & $27.29 \%$ & $4,643,522$ \\
\hline 2015 & $14,100,000$ & $1,995,216$ & $6,995,832$ & $28.52 \%$ & $5,000,616$ \\
\hline 2016 & $14,000,000$ & $2,079,430$ & $7,625,619$ & $27.27 \%$ & $5,546,189$ \\
\hline 2017 & $15,000,000$ & $2,391,793$ & $7,879,467$ & $30.35 \%$ & $5,487,674$ \\
\hline Total & $57,270,000$ & $8,208,981$ & $28,886,982$ & $28.42 \%$ & $20,678,001$ \\
\hline
\end{tabular}

Adapted from: Ministry of Finance. (2017). The KSA Budget of 2017. Riyadh: Ministry of Finance, Ministry of Finance. (2018). KSA Budget of 2018. Riyadh: Ministry of Finance, GAZT. (2016). Zakat contribution to the enhancement of social security. Riyadh: GAZT, and the researcher calculation of the Zakat from the banks' financial statements for years from 2014 to 2017. 
Appendix 2: Sample List

\begin{tabular}{|l|l|l|l|}
\hline No. & Name & Ticker Symbol & Trading name \\
\hline 1. & Riyad Bank & 1010 & RIBL \\
\hline 2. & Bank Aljazira & 1020 & BJAZ \\
\hline 3. & Saudi Investment Bank & 1030 & saib \\
\hline 4. & Alawwal Bank & 1040 & ALAWWAL \\
\hline 5. & Banque Saudi Fransi & 1050 & BSFR \\
\hline 6. & Saudi British Bank & 1060 & SABB \\
\hline 7. & Arab National Bank & 1080 & ARNB \\
\hline 8. & Samba Financial Group & 1090 & samba \\
\hline 9. & Al Rajhi Bank & 1120 & Al Rajhi \\
\hline 10. & Bank Albilad & 1140 & ALBILAD \\
\hline 11. & Alinma Bank & 1150 & Alinma \\
\hline 12. & National Commercial Bank & 1180 & NCB \\
\hline
\end{tabular}

As in Tadawul website, www.tadawul.com.sa.

Appendix 3:Study Variables

\begin{tabular}{|c|c|c|c|c|}
\hline Name & Year & $\begin{array}{c}\text { Book value per } \\
\text { share }\end{array}$ & $\begin{array}{l}\text { Adjusted book } \\
\text { value per share }\end{array}$ & $\begin{array}{c}\text { Market value per } \\
\text { share }\end{array}$ \\
\hline \multirow{4}{*}{ Inma } & 2014 & 11.96 & 11.71 & 20.25 \\
\hline & 2015 & 12.23 & 11.98 & 12.47 \\
\hline & 2016 & 12.79 & 12.52 & 14.18 \\
\hline & 2017 & 13.73 & 13.45 & 20.66 \\
\hline \multirow{4}{*}{ NCB } & 2014 & 23.46 & 23.28 & 38.73 \\
\hline & 2015 & 27.77 & 27.52 & 27.75 \\
\hline & 2016 & 29.96 & 29.72 & 27.11 \\
\hline & 2017 & 32.14 & 31.91 & 38.98 \\
\hline \multirow{4}{*}{ Awal } & 2014 & 22.55 & 22.31 & 17.74 \\
\hline & 2015 & 21.04 & 20.85 & 12.15 \\
\hline & 2016 & 11.08 & 10.89 & 11.70 \\
\hline & 2017 & 11.90 & 11.72 & 12.78 \\
\hline \multirow{4}{*}{ Bilad } & 2014 & 14.73 & 14.46 & 29.18 \\
\hline & 2015 & 12.88 & 12.64 & 15.01 \\
\hline & 2016 & 11.92 & 11.64 & 17.99 \\
\hline & 2017 & 12.65 & 12.32 & 20.85 \\
\hline \multirow{4}{*}{ BAJ } & 2014 & 15.40 & 15.08 & 20.99 \\
\hline & 2015 & 18.53 & 18.13 & 8.92 \\
\hline & 2016 & 20.26 & 19.74 & 9.38 \\
\hline & 2017 & 16.98 & 16.57 & 13.13 \\
\hline Rajhi & 2014 & 25.78 & 25.35 & 53.79 \\
\hline
\end{tabular}




\begin{tabular}{|c|c|c|c|c|}
\hline & 2015 & 28.70 & 28.22 & 45.36 \\
\hline & 2016 & 31.97 & 31.42 & 62.69 \\
\hline & 2017 & 34.31 & 33.78 & 71.05 \\
\hline \multirow{4}{*}{ Riyad } & 2014 & 11.85 & 11.56 & 17.05 \\
\hline & 2015 & 12.18 & 11.87 & 11.17 \\
\hline & 2016 & 12.32 & 11.99 & 10.76 \\
\hline & 2017 & 12.87 & 12.54 & 13.71 \\
\hline \multirow{4}{*}{ BSF } & 2014 & 21.96 & 21.53 & 31.90 \\
\hline & 2015 & 22.80 & 22.33 & 24.54 \\
\hline & 2016 & 24.64 & 24.14 & 23.05 \\
\hline & 2017 & 26.27 & 25.83 & 28.58 \\
\hline \multirow{4}{*}{ SIB } & 2014 & 19.75 & 19.28 & 22.22 \\
\hline & 2015 & 18.52 & 18.10 & 13.03 \\
\hline & 2016 & 19.05 & 18.58 & 13.31 \\
\hline & 2017 & 19.04 & 18.62 & 15.59 \\
\hline \multirow{4}{*}{ ANB } & 2014 & 20.60 & 20.35 & 31.53 \\
\hline & 2015 & 21.89 & 21.65 & 21.45 \\
\hline & 2016 & 23.24 & 22.97 & 20.15 \\
\hline & 2017 & 24.37 & 24.08 & 27.20 \\
\hline \multirow{4}{*}{ SABB } & 2014 & 26.07 & 25.70 & 37.68 \\
\hline & 2015 & 18.78 & 18.51 & 21.00 \\
\hline & 2016 & 20.85 & 20.53 & 21.80 \\
\hline & 2017 & 22.23 & 21.92 & 29.17 \\
\hline \multirow{4}{*}{ Samba } & 2014 & 32.32 & 31.83 & 24.81 \\
\hline & 2015 & 20.13 & 19.88 & 18.60 \\
\hline & 2016 & 21.22 & 20.97 & 22.73 \\
\hline & 2017 & 22.29 & 22.02 & 25.48 \\
\hline
\end{tabular}

Adapted from: Banks financial statements and the researcher calculation of the banks' financial statements information. 